Creating Worldviews 



\section{Creating Worldviews}

Metaphor, Ideology and Language

James W. Underhill

Edinburgh University Press 
(C) James W. Underhill, 20 I I

Edinburgh University Press Ltd

22 George Square, Edinburgh

www.euppublishing.com

Typeset in I I.5/I3 Monotype Ehrhardt by Servis Filmsetting Ltd, Stockport, Cheshire, and printed and bound in Great Britain by CPI Antony Rowe, Chippenham and Eastbourne

A CIP record for this book is available from the British Library

ISBN 978 o 748643 I 58 (hardback)

The right of James W. Underhill

to be identified as author of this work

has been asserted in accordance with

the Copyright, Designs and Patents Act I988.

Every effort has been made to trace the copyright holders, but if any have been inadvertently overlooked, the publisher will be pleased to make the necessary arrangements at the first opportunity. 